\title{
VegDunes - a coastal dune vegetation database for the analysis of Italian EU habitats
}

\author{
Irene Prisco, Marta Carboni \& Alicia Teresa Rosario Acosta
}

\begin{abstract}
In this paper we illustrate VegDunes (GIVD ID EU-IT-005), a vegetation database of Italian coastal dune EU habitats (sensu 92/43/EEC Habitats Directive). We explore general features of the data collected, in particular variation in plot size, time range of the relevés and geographical position accuracy. Then, we characterise and explore the spatial distribution of the different coastal dune habitats in the database, evidencing major biodiversity "hotspots" (areas with the highest number of habitats) at the national level. We collected previously published phytosociological information (2,666 phytosociological relevés) concerning Italian coastal dune vegetation (10 different EU habitats) that ranged from 1967 to 2011. Most relevés were recorded with a medium to high accuracy (from the exact GPS coordinates to a coastal length up to $5 \mathrm{~km}$ ) and the plot size did not exceed $100 \mathrm{~m}^{2}$. Habitats close to the sea-line were much more widespread along Italian coasts compared to more inland ones, possibly in relation with habitat loss caused by the intensification of human impact in back dune communities. Even though phytosociological databases are affected by preferential sampling issues, this kind of data is an important source of information for nature conservation, especially for threatened coastal environments. Overall, this information may be a powerful instrument for the future management of EU habitats from a conservation perspective.
\end{abstract}

Keywords: Coastal dune habitat; Habitats Directive; phytosociological database; psammophilous vegetation; UTM grid.

Received: 16 February 2012 - Accepted: 13 March 2012 - Co-ordinating Editor: Florian Jansen.

\section{Introduction}

In Europe there is a long tradition of vegetation survey based on the classical phytosociological approach (Braun Blanquet 1964, Westhoff \& van der Maarel 1973, Dierschke 1994, Dengler et al. 2008) which has proved to be a very useful methodological framework for local and regional overviews of vegetation types (Schaminée et al. 2009). In fact, the floristic-sociological approach makes it possible to describe and define characteristic vegetation groups in relatively small sample plots (usually between $1-100 \mathrm{~m}^{2}$ ) taking also environmental factors and biotic interactions into account (BottaDukát et al. 2007, Schaminée et al. 2007).

Millions of vegetation plots have been recorded for different purposes as well as a huge amount of metadata (Bekker et al. 2007). Nevertheless, the access to this massive but also scattered information was extremely limited prior to the advent of electronic database technologies and digital communication tools (Mucina \& van der Maarel 1989, Dengler et al. 2011).
In Italy huge amounts of phytosociological relevés have been performed (estimated in 150,000 samples according to Schaminée et al. 2009), although this information is often unpublished and not yet widely available on digital archives. However, many efforts in this regard are currently being carried out (Venanzoni et al. 2012). The compilation of a national vegetation-plot database is particularly urgent for Italian coastal dune habitats. The second National Report about the implementation of the 92/43/EEC Directive (the so called "Habitats Directive"; EEC 1992) indicates that among all 130 habitats listed in the Annex I for Italy, coastal dunes are one of the few types that fall within the category "unfavourable conservation state" (European Commission 2008, La Posta et al. 2008; Fig. 1).

The critically poor conservation conditions make these habitats those with the highest risk level and requiring special management measures in the near future (La Posta et al. 2008). In fact, even though the great diversity of Italian coastal dune habitats is widely recognised (Biondi et al. 2009), they are highly endangered not only by the increase of hu- man pressure on sandy littorals but also by massive coastal erosion coupled with missing space for natural coastal dynamics. Due to the combination of these factors dune habitats end up being compressed between the retreating coastline and the presence of human structures in the inland. Coupled with these phenomena are the effects of ongoing global climate change (Stanisci et al. 2004), which could cause alterations in the climate characteristics of the Mediterranean and changes in the sea-level, consequently affecting water resources, natural ecosystems (both terrestrial and marine), human activities (e.g. agriculture, recreation, tourism) and health (Giorgi \& Lionello 2008). Overall, the most threatened habitats are embryonic shifting dunes (EU habitat 2110), shifting dunes along the shoreline with Ammophila arenaria (EU habitat 2120), coastal dunes with Juniperus spp. (EU priority habitat $2250 *$ ) and Cisto-Lavanduletalia dune sclerophyllous scrubs (EU habitat 2260) (European Commission 2008, La Posta et al. 2008).

On such a basis we built a vegetation database of Italian coastal dune EU habitats (sensu 92/43/EEC Habitats Directive; 
EEC 1992), collecting previously published phytosociological information and georeferencing each relevé with a specified geographic accuracy level. Then we focused on the spatial distribution of the different coastal dune habitats based on the information available in the database. In this paper we aim to 1) increase the visibility of the database illustrating its main characteristics and its potential fu- ture uses, 2) highlighting likely biodiversity hotspots (areas with the highest number of habitats) for sandy coasts at the national level.

\section{VegDunes}

Scope: The database contains published and original phytosociological relevés of Italian coastal dunes. We considered only plant communities of Holocenic dunes. Each vegetation plot is associated to a habitat of Community interest (sensu "Habitats Directive" 92/43/EEC)

Status: ongoing capture Period: 1967-2011

Database manager(s): Irene Prisco (iprisco@uniroma3.it)

Owner: Laboratorio di Ecologia Vegetale, Dipartimento di Biologia Ambientale, Università Roma Tre, Rome, Italy

Web address: [NA]

Availability: according to a specific agreement

Online upload: [NA]

Export format(s): Turboveg

Database format(s): Turboveg

Online search: [NA]

Publication: Prisco I., Acosta A.T.R., Ercole S. (2012) An overview of the Italian coastal dune EU habitats. Annali di Botanica 2: $39-48$.

Plot type(s): normal plots

Non-overlapping plots: 2,666

Plot-size range: $0.2-500 \mathrm{~m}^{2}$

Total plot observations: 2,666

Estimate of existing plots: [NA]

Number of sources: 71

Completeness: [NA]

Valid taxa: $[N A]$

Countries: IT: $100.0 \%$

Forest: $0 \%$ - Non-forest: aquatic: $0 \%$; semi-aquatic: $0 \%$; arctic-alpine: $0 \%$; natural: $100 \%$; semi-natural: $0 \%$; anthropogenic: $0 \%$

Guilds: all vascular plants: $100 \%$

Environmental data: altitude: $5 \%$; slope aspect: $1 \%$; slope inclination: $3 \%$

Performance measure(s): cover: $100 \%$

Geographic localisation: GPS coordinates (precision $25 \mathrm{~m}$ or less): $2 \%$; point coordinates less precise than GPS, up to $1 \mathrm{~km}$ : $34 \%$; small grid (not coarser than $10 \mathrm{~km}): 39 \%$; political units or only on a coarser scale (>10 km): $26 \%$

Sampling periods: 1960-1969: 0.8\%; 1970-1979: 24.8\%; 1980-1989: 31.8\%; 1990-1999: 22.1\%; 2000-2009: 18.6\%; 2010-2019: 1.9\% Information as of 2012-07-19; further details and future updates available from http://www.givd.info/ID/EU-IT-005

\begin{tabular}{|l|}
\hline Habitat $2270^{*}$ \\
Wooded dunes with \\
Pinus pinea and/or \\
Pinus pinaster
\end{tabular}

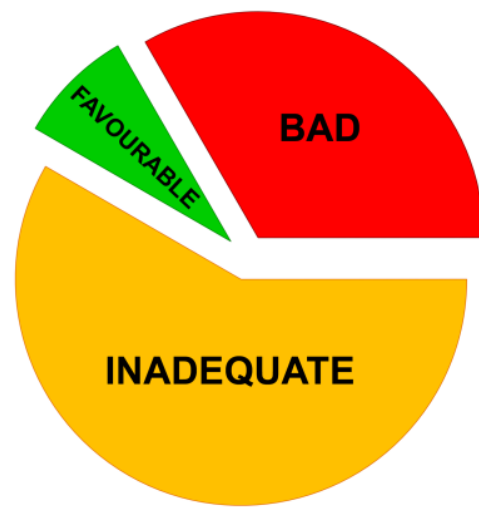

Habitat 2110 Embryonic shifting dunes

Habitat 2120 Shifting dunes along the shoreline with Ammophila arenaria

Habitat 2250* Coastal dunes with Juniperus spp.

Habitat 2260 Cisto-Lavanduletalia dune sclerophyllous scrubs

Habitat 1210 Annual vegetation of drift lines

Habitat 2130* Fixed coastal dunes with herbaceous vegetation

Habitat 2160 Dunes with Hippophae rhamnoides

Habitat 2190 Humid dune slacks

Habitat 2210 Crucianellion maritimae fixed beach dunes

Habitat 2230 Malcolmietalia dune grasslands

Habitat 2240 Brachypodietalia dune grasslands with annuals

Fig. 1: Conservation state of "Coastal Sand Dunes" and "Inland Dunes" (La Posta et al. 2008). Dune habitats show a high percentage of inadequate $(59 \%)$ and bad conservation state $(33 \%)$. Only one habitat show a favourable conservation state. ${ }^{*}=$ priority habitat. 


\section{Methods}

\section{Data collection}

We conducted a detailed research of the Italian phytosociological information by collecting accessible sources regarding Italian coastal dune vegetation, including mainly published literature (Appendix) but also some original data. We considered only plant communities of recent (Holocenic) dunes: fore dune, mobile dune, transition dune, fixed and inland dune. Thus, only phytosociological associations regarding these communities were selected. Specifically, we lead our bibliographical research by consulting all available issues of Italian journals reporting phytosociological relevés from the 1980s (e.g. Annali di Botanica, Informatore Botanico Italiano, Giornale Botanico Italiano, Fitosociologia. See Appendix for the complete list) and screening for vegetation surveys of coastal dunes in Italy. Then we searched for specific bibliography for each habitat through dedicated references reported in two main sources: the Italian Interpretation Manual of the 92/43/EEC Directive habitats (http://vnr. unipg.it/habitat/index.jsp) and the List of Italian Syntaxonomic Literature (LISY) which stores all citations of syntaxa and related bibliographic references published since 1909 for the Italian territory (http://www.scienzadellavegetazione.it/sis v/index.jsp). Finally, the search was integrated by directly inquiring many experts on these environments. The database is continuously updated based on information and literature sources made available to us.

After a first analysis of the collected information we identified areas with sandy coasts where no or very few relevés were available and conducted original phytosociological relevés in the spring of 2010 and 2011. In total we realized ca. 50 relevés distributed in the regions Lazio, Campania, Abruzzo, Molise and Puglia (all details in the database).

\section{Database construction and struc- ture}

The database was built using the software Turboveg (Hennekens \& Schaminée 2001). Although bryophytes and lichens are often abundant on the grey dune habitats in northern Europe (Houston 2008), no data about these species were available in the reference sources. We used as taxonomic reference list the species list of the Flora d'Italia (Pignatti 1982), the most commonly used in most of the relevés recorded. Cases of synonymy and taxonomical problems (see Jansen \& Dengler 2010) were resolved by relying on Conti et al. (2005), which report an updated list of synonyms with reference to the Flora d'Italia (Pignatti 1982).

For each relevé we also registered all metadata available from the reference sources, in particular sampling year, plot size, geographical location and phytosociological association. For the phytosociological associations we reported the original nomenclature of the primary reference sources. Based on the phytosociological classification of vegetation types provided in the reference source, each relevé was assigned to an EU habitat type following the guide-lines of the Italian Interpretation Manual of the 92/43/EEC Directive habitats (Biondi et al. 2009) and the Interpretation Manual of European Union Habitats (European Commission 2007).

The geographical position of each relevé allowed us to infer the spatial distribution of habitats at national level. In this regard, we should note that the description of the local geographical position of relevés varied, according to the reference source, from the exact geographical coordinates measured by Global Positioning System (GPS) to a general toponymic name. We used this information to georeference the relevés in decimal degrees through Google Earth, taking care to also assign an accuracy level. To this end, we proposed a scale of geographic accuracy, ranging from the lowest level of accuracy (if the toponym referred to a coast with a length over $5 \mathrm{~km}$ ), to a medium level (coast length between 3 and $5 \mathrm{~km}$ ) and finally to the highest level of accuracy (relevés with GPS coordinates, river outlets and small beaches -less than $3 \mathrm{~km}-$ ).

The database VegDunes is registered in the Global Index of Vegetation Database (GIVD, http://www.givd.info) with the code EU-IT-005. The GIVD is an on-line archive of metadata on vegetation databases whose primary goal is to facilitate the use of vegetation data through increasing its visibility and availability worldwide (Dengler et al. 2011).

\section{Brief analysis of the information in VegDunes and spatial distribution of relevés and habitats}

For comparison with other databases in GIVD, we briefly explored the variation in plot size, level of georeferentiation accuracy and time range of all relevés as of December 2011. We also characterised each EU habitat in terms of the number of relevés available, the plot size range, the most abundant species and the number of different phytosociological associations. To analyse the spatial distribution of Italian coastal EU habitats contained in VegDunes, the information associated with each relevé was transferred into a $10 \mathrm{~km} \times 10 \mathrm{~km}$ UTM grid, which is the spatial resolution most commonly used in regional and national analyses (Hassall \& Thompson 2010), using a GIS software (ESRI Inc. 2006). Grid squares are commonly used to analyse habitats and species distribution patterns because this simple method is applicable to any amount of data (Bombi et al. 2011). In fact, information on the habitat types and species listed in the Annexes of the Habitats Directive (EEC 1992) has been aggregated at European level and organised on the UTM grid (European Commission 2008). Thus, we first calculated the number of relevés in each $10 \mathrm{~km} \times 10 \mathrm{~km}$ UTM grid square. Then, we produced grid distribution maps for each EU coastal dune habitat identified. Finally, with the aim of identifying diversity hotspots, we calculated the total number of EU habitats for each grid square.

\section{Results}

\section{VegDunes - Database of Italian coastal dune vegetation}

Overall, the coastal dune vegetation database includes 2,666 phytosociological relevés related to the Italian peninsula and islands, 2,618 being from published sources (Appendix) and 48 being original data. The oldest plot in the database is dated 1967, whereas the newest is dated 2011, although most of the data comes from the 1980s till present (75\%; Fig. 2). Regarding the geographic accuracy of the database, it is worth noting that most relevés were recorded with a medium and high accuracy (74\%) and only $26 \%$ had a coarser accuracy. 


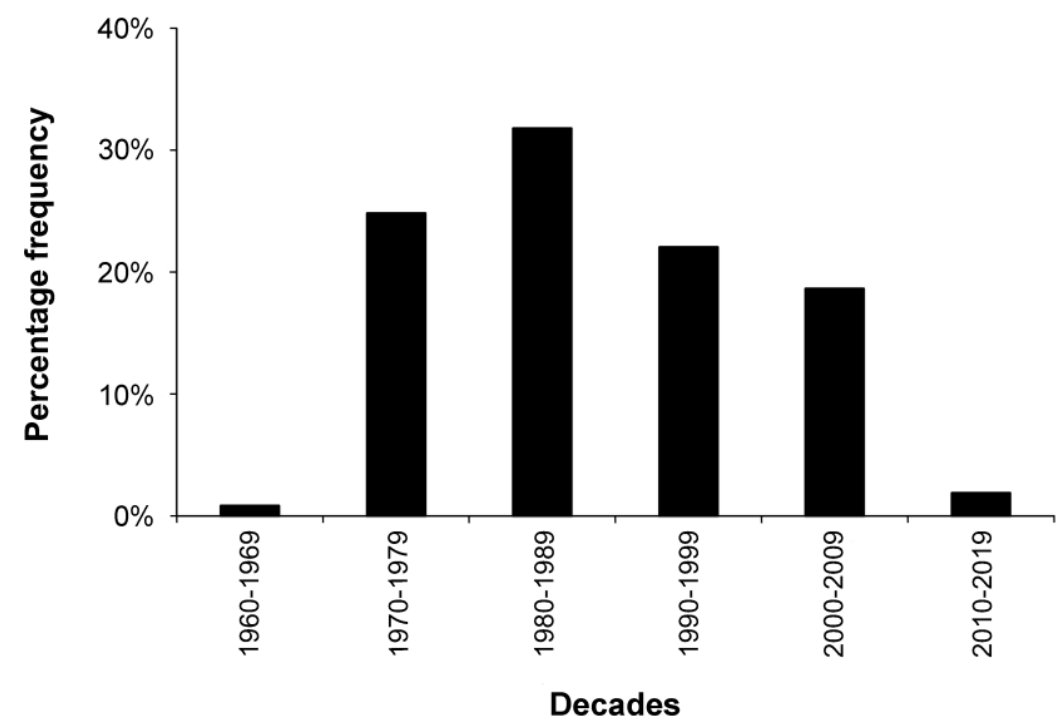

Fig. 2: Proportion of relevés recorded in each decade. We observed that most of relevés have been conducted since the 1980 s to the present $(75 \%)$, so we could affirm that the information in the database is relatively recent.

We noted that geographic accuracy increased slightly from the year 2000 up to the present (probably due to the recent widespread use of precision instruments as the GPS); however, relevés with a high geographic accuracy were available for the whole time range covered by the database. Sampling size varied from 1 to $300 \mathrm{~m}^{2}$, but in most cases sampling plots were not larger than $100 \mathrm{~m}^{2}$ (70\%; Fig. 3). In particular, fore dune herbaceous vegetation (e.g. EU habitat 1210, 2110, 2120) was usually sampled in plots up to $100 \mathrm{~m}^{2}$, whereas in fixed dune perennial vegetation (e.g. EU habitat 2250*, 9340) plots could reach up to $300 \mathrm{~m}^{2}$. We observed that in recent years relevés have tended to be smaller (they do not exceed $100 \mathrm{~m}^{2}$ after 2000).

\section{Coastal dune EU habitats}

Coastal dune relevés were distributed in 10 different EU habitats (Tab. 1). In the original sources 90 phytosociological associations have been described, however some of them probably include many synonyms, so the number of associations could be overestimated. Habitats concerning mobile dune and transition dune (EU habitat $2110,2120,2210$ ) have the highest number of records, followed by fore dune and fixed dune habitats (EU habitat $1210,2230,2250 *)$. database focused on coastal dune vegetation. A national database for botanical data is currently being assembled (VegItaly, Venanzoni et al. 2012): this is an ambitious project collecting not only vegetation plots, but also information about Italian flora, taxonomy and herbarium records (http://www.anarchive.it/ anArchive/index.jsp). VegDunes instead concentrates exclusively on coastal sand dunes habitats, aiming to a detailed characterisation of the vegetation of these threatened environments. At the moment VegDunes already includes almost 3,000 records distributed in a limited number of vegetation types (10 EU habitats) most of them with a consistent number of samples. In particular, we found that those habitats close to the sea-line were much more widespread compared to more inland ones. One possible explanation is that inland dune habitats have been less preserved as they have been often transformed into areas suitable for agriculture activities or urban development. The intensification of human presence in back dune communities has led to the increase of water catchment, pine plantation and tourist activities (Acosta et al. 2000, 2006), with the consequent decrease of more inland coastal dune habitats.

Considering all habitats together, based on the information contained in VegDunes, we can identify areas of high biodiversity, which are likely to be the most important for conservation purposes. Specifically, we highlighted that central Italy and the major islands seem to have the highest concentration of coastal dune habitats. These "hotspots" are possibly related to particularly well-preserved coastal dune vegetation systems (Brullo et al. 2001). The inclusion of such areas in the national reserve network or in conservation programs can be of fundamental importance for the ability of protecting these habitats and all the organisms that they harbour on the long-term.

Several biases typically influence the patterns highlighted by means of large electronic vegetation databases. As these databases are compiled using numerous literature sources, phytosociological relevés are usually unevenly distributed over time and space, and in terms of authorship (Haveman \& Janssen 2008). Most common sources of heterogeneity include: geographic positioning accuracy, plot size, sampling effort and the time range covered by all relevés in the database. 
A

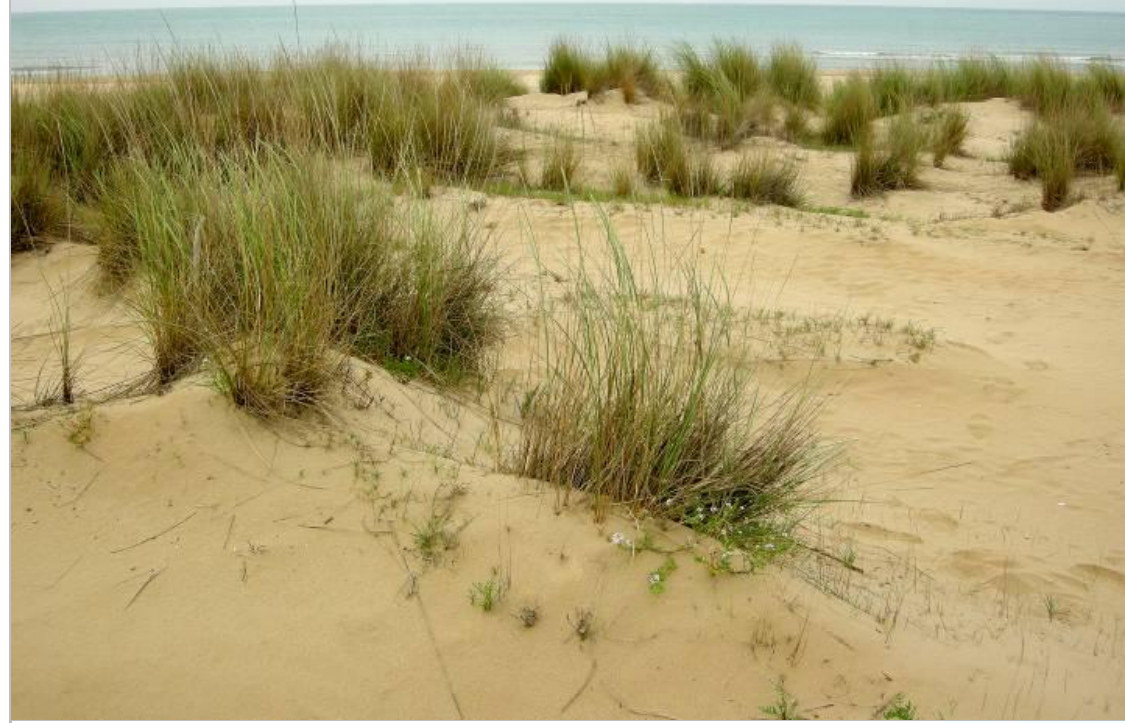

B

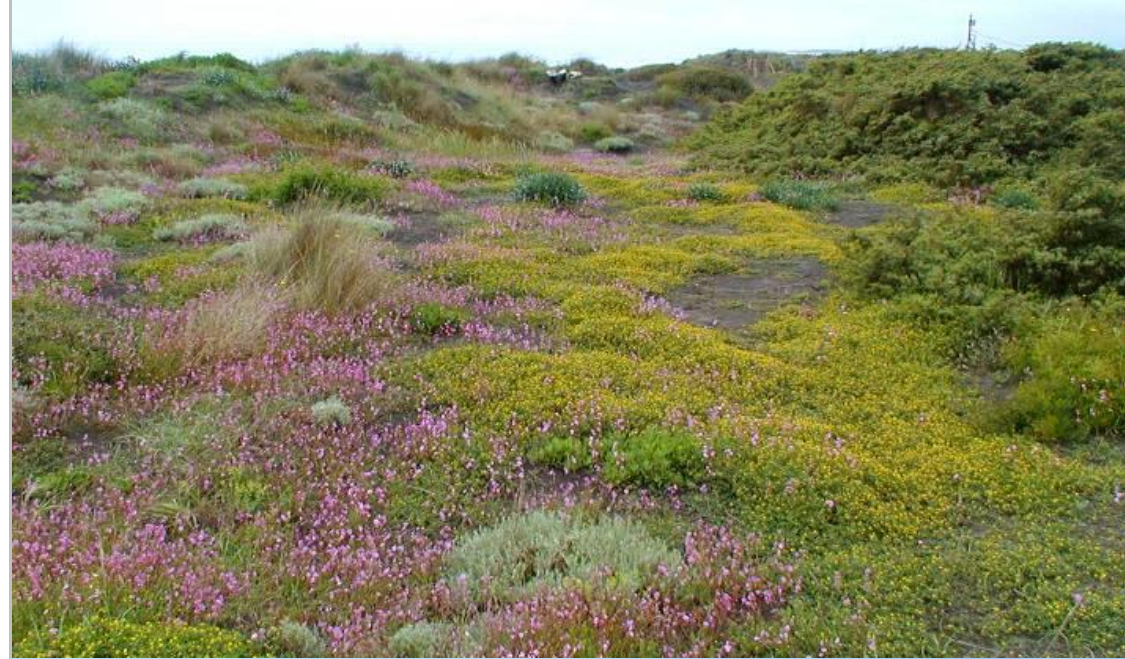

C

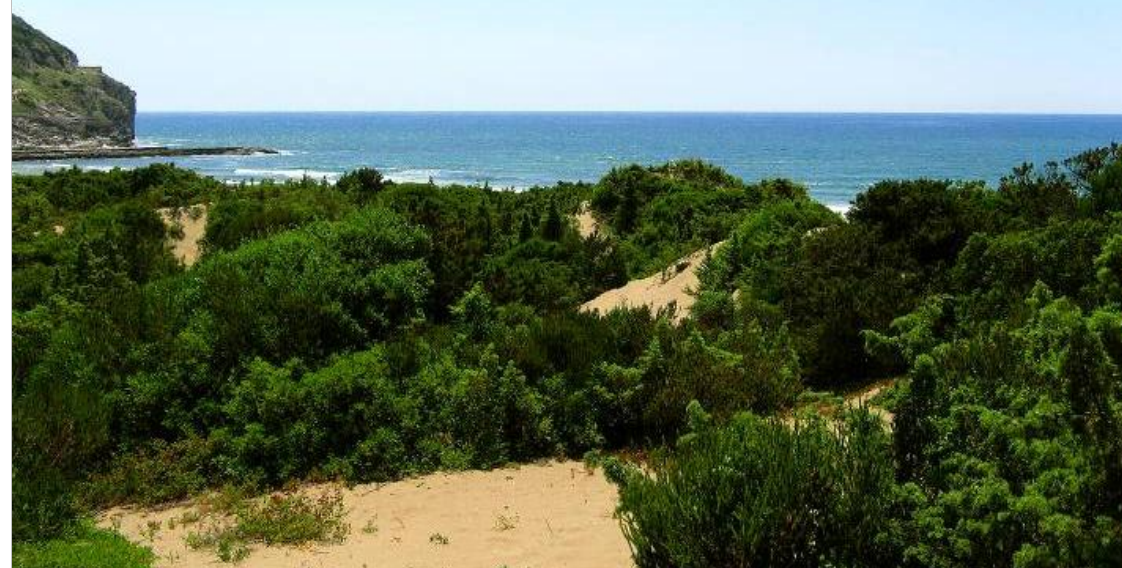

Plate: Vegetation types featured by the vegetation-plot database GIVD EU-IT005:

A: Shifting dunes along the shoreline with Ammophila arenaria (EU habitat 2120) in Punta Aderci (Vasto, Abruzzo).

B: Malcolmietalia dune grasslands (EU habitat 2230) in Tarquinia (Rome, Lazio).

C: Coastal dunes with Juniperus spp. (EU priority habitat $2250^{\star}$ ) at Circeo National Park (Latina, Lazio) 
Table 1: Summary of the 10 coastal EU habitats $\left({ }^{*}=\right.$ priority habitat) within the database. For each habitat was reported information regarding relevés, most frequent species and phytosociological associations. Species names were updated according to the recent checklist of the Italian Flora (Conti et al. 2005).

\begin{tabular}{|c|c|c|c|c|c|c|}
\hline \multirow[b]{2}{*}{ Habitat } & \multicolumn{2}{|c|}{ Relevés } & \multicolumn{2}{|c|}{ Species } & \multicolumn{2}{|c|}{ Phytosociological associations } \\
\hline & $\begin{array}{l}\text { Tot } \\
n^{\circ}\end{array}$ & $\begin{array}{l}\% \text { of } \\
\text { Tot. }\end{array}$ & $\begin{array}{r}\text { Tot } \\
n^{\circ}\end{array}$ & $\begin{array}{l}\text { Most abundant } \\
\text { (frequency }>40 \% \text { ) }\end{array}$ & $\begin{array}{l}\text { Tot } \\
n^{\circ}\end{array}$ & Most frequent \\
\hline $\begin{array}{l}1210 \\
\text { Annual vegetation of } \\
\text { drift lines }\end{array}$ & 376 & $14.10 \%$ & 123 & $\begin{array}{l}\text { Cakile maritima, Salsola kali, Xan- } \\
\text { thium orientale }\end{array}$ & 10 & $\begin{array}{l}\text { Salsolo kali-Cakiletum mariti- } \\
\text { mae, Salsolo kali- } \\
\text { Euphorbietum peplis, } \\
\text { Cakiletum maritimae- } \\
\text { Xanthietum italici }\end{array}$ \\
\hline $\begin{array}{l}2110 \\
\text { Embryonic shifting } \\
\text { dunes }\end{array}$ & 568 & $21.30 \%$ & 168 & $\begin{array}{l}\text { Elymus farctus, Eryngium mariti- } \\
\text { mum, Echinophora spinosa, Cakile } \\
\text { maritima, Medicago marina, Otan- } \\
\text { thus maritimus, Sporobolus virgini- } \\
\text { cus, Pancratium maritimum }\end{array}$ & 9 & $\begin{array}{l}\text { Elymetum farcti, Echinophoro } \\
\text { spinosae-Elymetum farcti, } \\
\text { Sporobolo arenarii-Elymetum } \\
\text { farcti }\end{array}$ \\
\hline $\begin{array}{l}2120 \\
\text { Shifting dunes along } \\
\text { the shoreline with } \\
\text { Ammophila arenaria } \\
\text { (white dunes) }\end{array}$ & 506 & $19.00 \%$ & 241 & $\begin{array}{l}\text { Ammophila arenaria, Eryngium mari- } \\
\text { timum, Echinophora spinosa, Ely- } \\
\text { mus farctus, Euphorbia paralias }\end{array}$ & 6 & $\begin{array}{l}\text { Ammophiletum arundinaceae, } \\
\text { Echinophoro spinosae- } \\
\text { Ammophiletum arundinaceae }\end{array}$ \\
\hline $\begin{array}{l}2130^{\star} \\
\text { Fixed coastal dunes } \\
\text { with herbaceous vege- } \\
\text { tation } \\
\text { (grey dunes) }\end{array}$ & 21 & $0.80 \%$ & 74 & $\begin{array}{l}\text { Fumana procumbens, Oenothera } \\
\text { biennis, Scabiosa argentea, } \\
\text { Teucrium chamaedrys, Teucrium } \\
\text { polium, Cyperus kalli, Silene vul- } \\
\text { garis, Ammophila littoralis, Koeleria } \\
\text { macrantha, Petrorhagia saxifraga, } \\
\text { Stachys recta, Helianthemum } \\
\text { jonium, Hypochoeris radicata, Tor- } \\
\text { tula ruraliformis, Ambrosia maritima, } \\
\text { Calystegia soldanella, Silene otites, } \\
\text { Dactylis glomerata, Helichrysum } \\
\text { italicum, Sanguisorba minor, Phleum } \\
\text { arenarium }\end{array}$ & 1 & Tortulo-Scabiosetum \\
\hline $\begin{array}{l}2210 \\
\text { Crucianellion mariti- } \\
\text { mae fixed beach } \\
\text { dunes }\end{array}$ & 462 & $17.30 \%$ & 289 & $\begin{array}{l}\text { Crucianella maritima, Pancratium } \\
\text { maritimum, Helichrysum italicum, } \\
\text { Lotus cytisoides }\end{array}$ & 19 & $\begin{array}{l}\text { Crucianelletum maritimae, } \\
\text { Centaureo sphaerocephalae- } \\
\text { Ononidetum ramosissimae, } \\
\text { Helichryso microphylli- } \\
\text { Crucianelletum maritimae, } \\
\text { Pycnocomo rutifolii- } \\
\text { Crucianelletum maritimae }\end{array}$ \\
\hline $\begin{array}{l}2230 \\
\text { Malcolmietalia dune } \\
\text { grasslands }\end{array}$ & 333 & $12.50 \%$ & 361 & $\begin{array}{l}\text { Vulpia fasciculata, Lagurus ovatus, } \\
\text { Silene colorata, Rumex bucephalo- } \\
\text { phorus, Medicago litoralis }\end{array}$ & 20 & $\begin{array}{l}\text { Vulpio-leopoldietum gussonei, } \\
\text { Sileno coloratae-Vulpietum } \\
\text { membranaceae, Sileno colora- } \\
\text { tae-Ononidetum variegatae, } \\
\text { Glaucio flavi-Matthioletum tri- } \\
\text { cuspidatae }\end{array}$ \\
\hline $\begin{array}{l}2240 \\
\text { Brachypodietalia dune } \\
\text { grasslands with annu- } \\
\text { als }\end{array}$ & 23 & $0.90 \%$ & 109 & $\begin{array}{l}\text { Rumex bucephalophorus, Lotus an- } \\
\text { gustissimus, Coleostephus myconis, } \\
\text { Tuberaria guttata }\end{array}$ & 3 & $\begin{array}{l}\text { Euphorbio terracinae- } \\
\text { Hyparrhenietum hirtae, } \\
\text { Moenchio-Tuberarietum guttati, } \\
\text { Psiluro-Crassuletum tillaeae }\end{array}$ \\
\hline $\begin{array}{l}2250^{*} \\
\text { Coastal dunes with } \\
\text { Juniperus spp. }\end{array}$ & 238 & $8.90 \%$ & 254 & $\begin{array}{l}\text { Juniperus oxycedrus, Pistacia lentis- } \\
\text { cus, Rubia peregrina, Smilax as- } \\
\text { pera, Asparagus acutifolius, } \\
\text { Phillyrea angustifolia, Juniperus } \\
\text { phoenicea }\end{array}$ & 9 & $\begin{array}{l}\text { Asparago acutifolii- } \\
\text { Juniperetum macrocarpae, Pis- } \\
\text { tacio lentisci-Juniperetum mac- } \\
\text { rocarpae, Junipero-Quercetum } \\
\text { calliprini, Phillyreo angustifo- } \\
\text { liae-Juniperetum turbinatae }\end{array}$ \\
\hline $\begin{array}{l}2260 \\
\text { Cisto-Lavanduletalia } \\
\text { dune sclerophyllous } \\
\text { scrubs }\end{array}$ & 100 & $3.75 \%$ & 225 & $\begin{array}{l}\text { Rubia peregrina, Asparagus acuti- } \\
\text { folius, Pistacia lentiscus, Cistus } \\
\text { salvifolius, Phillyrea latifolia, Sixalix } \\
\text { atroporpurea, Smilax aspera }\end{array}$ & 9 & $\begin{array}{l}\text { Phillyreo latifoliae-Ericetum } \\
\text { scopariae, Loto-Thymetum } \\
\text { capitati }\end{array}$ \\
\hline $\begin{array}{l}9340 \\
\text { Quercus ilex and } \\
\text { Quercus rotundifolia } \\
\text { forests }\end{array}$ & 39 & $1.45 \%$ & 92 & $\begin{array}{l}\text { Smilax aspera, Quercus ilex, Pis- } \\
\text { tacia lentiscus, Rubia peregrina, As- } \\
\text { paragus acutifolius, Phillyrea angus- } \\
\text { tifolia, Lonicera implexa, Clematis } \\
\text { flammula, Arbutus unedo, Hedera } \\
\text { helix, Myrtus communis, Phillyrea } \\
\text { latifolia, Ruscus aculeatus }\end{array}$ & 4 & $\begin{array}{l}\text { Phillyreo angustifoliae- } \\
\text { Ericetum multiflorae, } \\
\text { Quercetum ilicis, Pistacio lenti- } \\
\text { sci-Rhamnetum alaterni }\end{array}$ \\
\hline
\end{tabular}


Most relevés in the database are registered with a medium-high geographic accuracy. We show here that relevés with this accuracy level can easily be transferred into a $10 \mathrm{~km} \times 10 \mathrm{~km}$ UTM grid. This procedure not only allows a clear presentation of their spatial distribution at national scale but can also contribute to avoid the influence of small position errors of relevés. As far as plot size is concerned, variation in dimensions is wellknown in phytosociological surveys (Chytrý \& Otýpková 2003). As van der Maarel (1975) pointed out, phytosociological relevés extension depend on the type of sampled vegetation. The largest plots $\left(25-200 \mathrm{~m}^{2}\right)$ are usually used for woodlands, scrubs or for species-poor or very open vegetation types, whereas for herbaceous and grasslands vegetation smaller plots are usually used $\left(5-50 \mathrm{~m}^{2}\right)$ (Westhoff \& van der Maarel 1973, Dierschke 1994, Chytrý 2001). The plot size variations in our database reflect this general rule: smaller plots for fore dune and mobile dune and larger ones for woody vegetation on fixed dunes. Regarding sampling effort, results could be influenced by the different phytosociological traditions developed in the different regions, as some areas could have been traditionally more studied than others. Field researchers could also be hindered by time availability and budget (Kueper et al. 2006). In our case, visual inspection of the number of relevés per grid square shows that some squares have received greater sampling effort, but these are quite scattered throughout the peninsula and not concentrated in few specific regions. Besides, these more thoroughly sampled squares overlap only partially with the areas identified as diversity hotspots, suggesting that differences in sampling effort have limited influence on the distribution patterns highlighted. Despite the wide time range of the relevés we observed that most of them have been conducted since the 1980 s to the present. Thus, the information is relatively recent and it probably reflects current knowledge concerning the Italian coastal dune vegetation. However, we are conscious that some habitats could have been overestimated in some areas due to a more recent habitat loss while others could have been underestimated.

The application of the phytosociological approach provides advantages and disadvantages, as pointed out by several authors (Botta-Dukák et al. 2007, Chiarucci 2007, Diekmann et al. 2007, Hédl

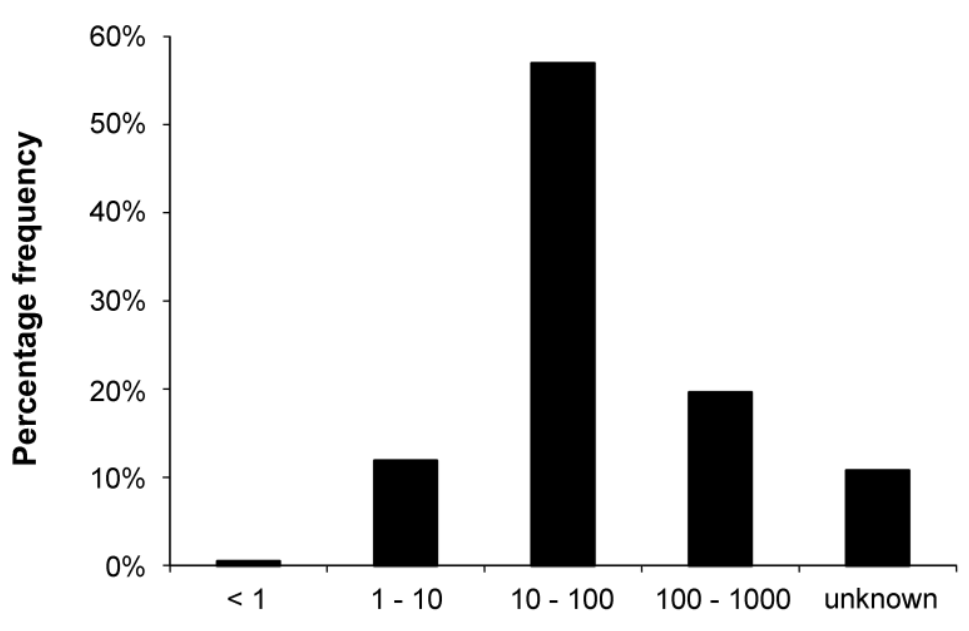

Plot size [m2]

Fig. 3: Plot size distribution of the relevés in the database. In most cases sampling plots were not larger than $100 \mathrm{~m}^{2}(\mathbf{7 0 \%})$. Larger plots were usually used for back and inland dunes habitats.

2007, Lájer 2007, Roleček et al. 2007, Michalcová et al. 2011). Subjective field selection, that characterises phytosociological relevés, is probably the best strategy for capturing diverse sites (local "hotspots") which are usually of a very small extent (Hédl 2007), in particular considering the localised habitats of coastal dunes. In this situation random sampling may miss some vegetation types. An often mentioned drawback of phytosociology is the difficulty (or even the impossibility) of not to under- or oversample some particular vegetation types (Hédl 2007). Moreover, preferential sampling may lead to biased results due to violation of statistical assumptions of randomness and independence of observations (Kershaw \& Looney 1985, Chiarucci 2007, Lájer 2007). Therefore, the frequency and distribution of habitat types we report on the basis of the information stored in VegDunes should serve as a general indication rather than a precise account of the current distribution. The use of habitat distribution modelling can potentially help overcome these drawbacks in the future (Bittner et al. 2011).

In conclusion, the information derived from this database gives an excellent account of the diversity of Italian coastal dune habitat types, and thereby serves as an important tool for nature conservation.
In particular, this information may be useful for the future management of EU habitats from a conservation perspective. In fact, large vegetation databases could be relevant for the effective implementation of the Natura 2000 Network (Shaminée et al. 2011). Information derived from this database could be overlapped with the Natura 2000 Network with the aim of identifying major gaps. By contrast, the identification of areas with the highest concentration of habitats may constitute the first step to proposing new protected areas in cases where such areas have not yet been demarcated.

Finally, the information contained in VegDune database could be used for several further scopes. For example, it could be combined with information on morpho-functional traits (e.g. SynBioSys Europe; Schaminée et al. 2007) or with abiotic data such as climatic, geomorphological or edaphic strata (Coudun \& Gégout 2007) to highlight possible causes of present day distribution patterns. This information would also help to evaluate the response of coastal dune habitats to different global change scenarios (Ozinga et al. 2005) and to estimate future possible range shifts for long-term conservation efforts (Elith \& Leathwick 2009, Seo et al. 2009). 

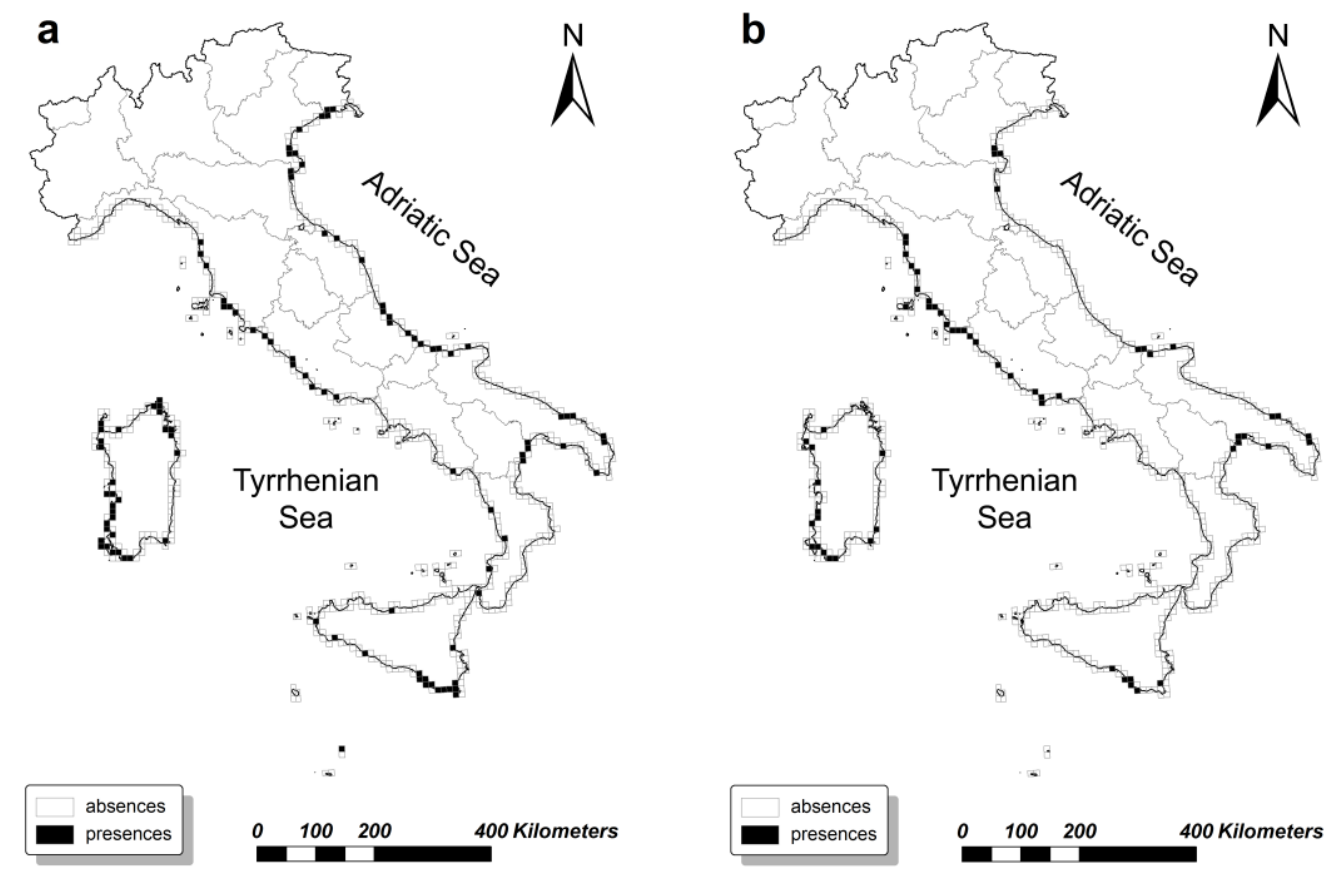

Fig. 4: Comparison between the geographical distribution of (a) a fore dune habitat 2120 Shifting dunes along the shoreline with Ammophila arenaria (white dunes) and (b) a back dune habitat $2250^{\star}$ Coastal dunes with Juniperus spp.. We found that habitats close to the sea-line were much more widespread compared to more inland ones.
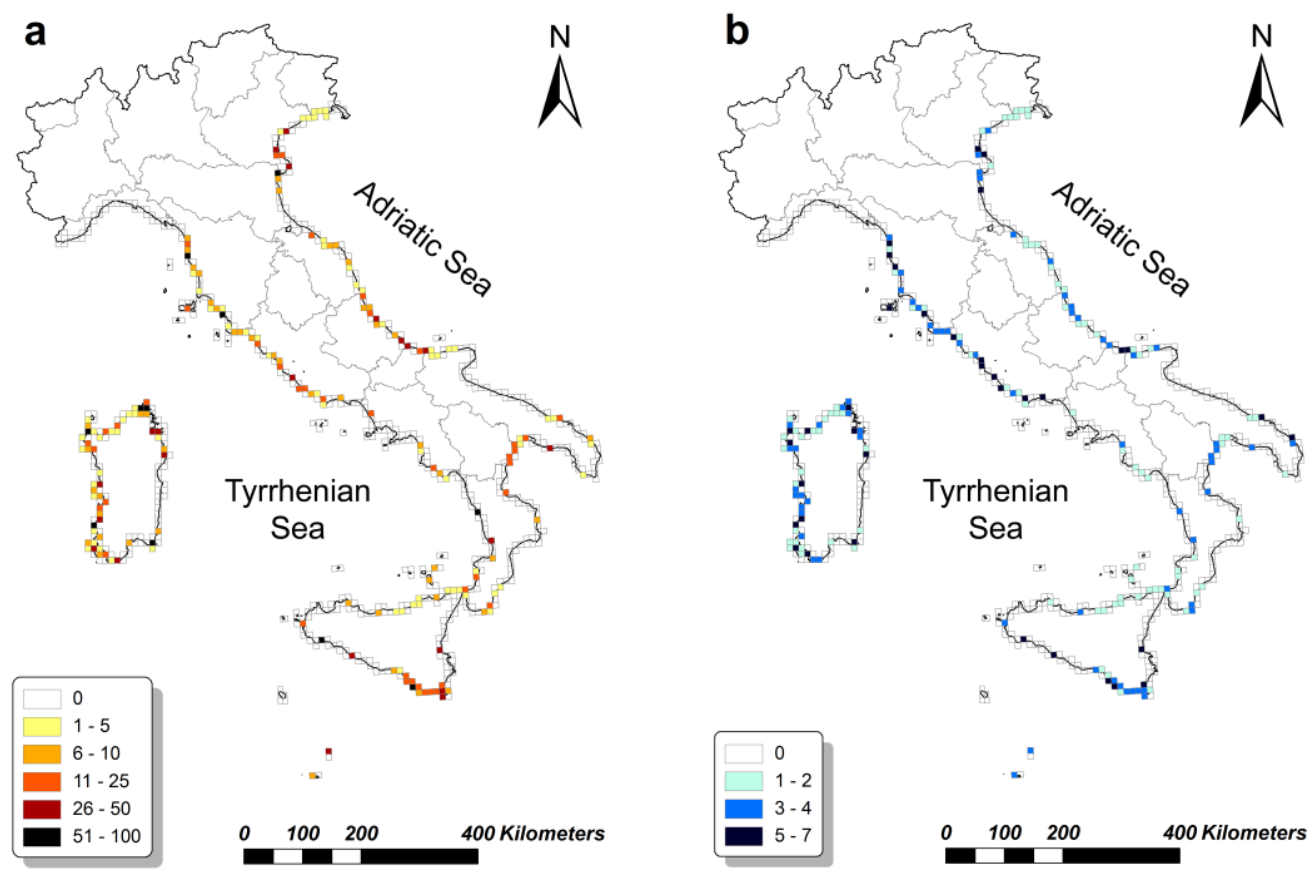

Fig. 5: (a) Total number of relevés and (b) number of EU habitats in each grid square (UTM grid $10 \mathrm{~km} \times 10 \mathrm{~km}$ ). Although relevés were widely distributed throughout the Italian coasts, we localised areas with high concentration of habitats, particularly in central Italy (including both Tyrrhenian and Adriatic coasts), in the two major islands (Sicily and Sardinia) and along the North Adriatic Sea. 


\section{Acknowledgements}

We are grateful to Stefania Ercole, Giovanni De Marco, Laura Cancellieri and Maurizio Cutini for helping in bibliographic researches and phytosociological associations. We would like to thank Angela Stanisci, Riccardo Santoro and Silvia Del Vecchio for their help with sampling in the field. We thank Martin Bennett for language editing. Finally we are grateful to Jürgen Dengler and Florian Jansen for their useful comments on the manuscript.

\section{References}

Acosta, A.T.R., Blasi., C., Stanisci, A. (2000): Spatial connectivity and boundary patterns in coastal dune vegetation in the Circeo National Park, Central Italy. - Journal of Vegetation Science 11: 149-154. CrossRef

Acosta, A.T.R., Ercole, S., Stanisci, A., Blasi, C. (2006): Sandy coastal ecosystems and effects of disturbance in central Italy. - Journal of Coastal Research 39: 985-989.

Bekker, R.M., van der Maarel, E., Bruelheide, H., Woods, K. (2007): Long-term datasets: from descriptive to predictive data using ecoinformatics. - Journal of Vegetation Science 18: 457-462. CrossRef

Biondi, E., Blasi, C., Burrascano, S., Casavecchia, S., Copiz, R., Del Vico, E., Galdenzi, D., Gigante, D., Lasen, C., Spampinato, G., Venanzoni, R., Zivkovic, L. (2009): Manuale Italiano di interpretazione degli habitat della Direttiva 92/43/CEE (Italian Interpretation Manual of the 92/43/EEC Directive habitats). URL: http://vnr.unipg.t//habitat/index.jsp .

Bittner, T., Jaeschke, A., Reineking, B., Beierkuhnlein, C. (2011): Comparing modelling approaches at two levels of biological organisation - Climate change impacts on selected Natura 2000 habitats. - Journal of Vegetation Science 22: 699-710. CrossRef

Bombi, P., Luiselli, L., D'Amen, M. (2011): When the method for mapping species matters: defining priority areas for conservation of African freshwater turtles. Diversity and Distributions 17: 581-592. CrossRef

Botta-Dukát, Z., Kovács-Láng, E., Rédei, T., Kertész, M., Garadnai, J. (2007): Statistical and biological consequences of preferential sampling in phytosociology: theoretical considerations and a case study. - Folia Geobotanica 42: 141-152.

Braun-Blanquet, J. (1964): Pflanzensoziologie. Grundzüge der Vegetationskunde. 3rd Edition - Wien-New York: Springer.

Brullo, S., Giusso del Galdo, G.P., Siracusa, G., Spampinato, G. (2001): Considerazioni fitogeografiche sulla vegetazione psammofila dei litorali italiani. - Biogeographia 22

Chiarucci, A. (2007): To sample or not to sample? That is the question ... For the vegetation scientist. - Folia Geobotanica 42: 209-216. CrossRef

Chytrý, M. (2001): Phytosociological data give biased estimates of species richness. - Journal of Vegetation Science 12: 439-444.

Chytrý, M., Otýpková, Z. (2003): Plot sizes used for phytosociological sampling of European vegetation. - Journal of Vegetation Science 14: 563-570.

Conti, F., Abbate, G., Alessandrini, A., Blasi, C. [Eds.] (2005): An Annotated Checklist of the Italian Vascular Flora. - Ministero dell'Ambiente e della Tutela del Territorio, Dipartimento di Biologia Vegetale, Università degli Studi di Roma "La Sapienza". Roma: Palombi Editori.

Coudun, C., Gégout, J.C. (2007): Quantitative prediction of the distribution and abundance of Vaccinium myrtillus with climatic and edaphic factors. - Journa of Vegetation Science 18: 517-524. CrossRef

Dengler, J., Chytrý, M., Ewald, J. (2008): Phytosociology. - In: Jørgensen, S.E., Fath B.D. [Eds.]: Encyclopedia of ecology 4: 2767-2779. Oxford: Elsevier.

Dengler, J., Jansen, F., Glöckler, F., Peet, R.K., De Cáceres, M., Chytrý, M., Ewald, J., Oldeland, J., Lopez-Gonzalez, G., Finckh, M., Mucina, L., Rodwell, J.S., Schaminée, J.H.J., Spencer, N. (2011) The Global Index of Vegetation-Plot Databases (GIVD): a new resource for vegetation science. - Journal of Vegetation Science 22: 582-597. CrossRef

Diekmann, M., Kühne, A., Isermann, M. (2007): Random vs non-random sampling: effects on patterns of species abundance, species richness and vegetation-environment relationships. - Folia Geobotanica 42: 179-190. CrossRef

Dierschke, H. (1994): Pflanzensoziologie. - Stuttgart: Ulmer.

EEC (1992): Council Directive 92/43/EEC of 21 May 1992 on the conservation of natural habitats and of wild fauna and flora. - Official Journal L. $\mathrm{n}^{\circ} 206$ 22/07/1992.

Elith, J., Leathwick, J.R. (2009): Species distribution models: ecological explanation and prediction across space and time. - Annual Review of Ecology, Evolution and Systematics 40: 677-697. CrossRef

ESRI Inc. (2006): ArcGIS. Version 9.2. Redlands, CA.

European Commission DG Environment (2007) [Ed.]: Interpretation manual of European Union habitats - EUR 27. Brussels: European Commission DG Environment.

European Commission DG Environment (2008): Article 17 Technical Report 2001-2006. - European Topic Centre on
Biological Diversity. URL: http:// biodiversity.eionet.europa.eu/article17.

Giorgi, F., Lionello, P. (2008): Climate change projections for the Mediterranean region. - Global and Planetary Change 63: 90-104. CrossRef

Hassall, C., Thompson, D.J. (2010): Accounting for recorder effort in the detection of range shifts from historical data. Methods in Ecology and Evolution 1: 343-350. CrossRef

Haveman, R., Janssen, J.A.M. (2008): The analysis of long-term changes in plant communities using large databases: The effect of stratified resampling. - Journal of Vegetation Science 19: 355-362. CrossRef

Hédl, R. (2007): Is sampling subjectivity a distorting factor in surveys for vegetation diversity? - Folia Geobotanica 42: 191198.

Hennekens, S.M., Schaminée, J.H.J. (2001): TURBOVEG, a comprehensive database management system for vegetation data. - Journal of Vegetation Science 12: 589-591. CrossRef

Houston, J. (2008): Management of Natura 2000 habitats. 2130 *Fixed coastal dunes with herbaceous vegetation ("grey dunes"). - European Commission.

Jansen, F., Dengler, J. (2010): Plant names in vegetation databases - a neglected source of bias. - Journal of Vegetation Science 21: 1179-1186. CrossRef

Kershaw, K.A., Looney, J.H.H. (1985): Quantitative and dynamic plant ecology. - London (UK): Edward Arnold.

Kueper, W., Sommer, J.H., Lovett, J.C., Barthlott, W. (2006): Deficiency in African plant distribution data - missing pieces of the puzzle. - Botanical Journal of the Linnean Society 150: 355-368.

La Posta, A., Duprè, E., Bianchi, E. (2008): Attuazione della Direttiva Habitat e stato di conservazione di habitat e specie in Italia. - Ministero dell'Ambiente e della Tutela del Territorio e del Mare.

Lájer, K. (2007): Statistical tests as inappropriate tools for data analysis performed on non-random samples of plant communities. - Folia Geobotanica 42: 115-122.

Michalcová, D., Lvončík, S., Chytrý, M., Hájek, O. (2011): Bias in vegetation databases? A comparison of stratifiedrandom and preferential sampling. Journal of Vegetation Science 22: 281291.

Mucina, L., van der Maarel, E. (1989): Twenty years of numerical syntaxonomy. - Vegetatio 81: 1-15. CrossRef

Ozinga, W.A., Hennekens, S.M., Schaminée, J.H.J., Bekker, R.M., Prinzing, A., Bonn, S., Poschlod, P., Tackenberg, O., Thompson, K., Bakker, J.P., van Groenendael, J.M. (2005): Assessing the relative importance of dispersal in plant communities using an ecoinformatics 
approach. - Folia Geobotanica 40: 5367. CrossRef

Pignatti, S. (1982): Flora d'Italia - Bologna: Edagricole.

Roleček, J., Chytrý, M., Hájek, M., Lvončik, S., Tichý, L. (2007): Sampling design in large-scale vegetation studies: do not sacrifice ecological thinking to statistical purism! - Folia Geobotanica 42: 199208.

Schaminée, J.H.J., Hennekens, S.M., Chytrý, M., Rodwell, J.S. (2009): Vegetation-plot data and databases in Europe: an overview. - Preslia 81: 173185.

Schaminée, J.H.J., Hennekens, S.M., Ozinga, W.A. (2007): Use of the ecological information system SynBioSys for the analysis of large datasets. - Journal of Vegetation Science 18: 463-470.

Schaminée, J.H.J., Janssen, J.A.M., Hennekens, S.M., Ozinga, W.A. (2011): Large vegetation databases and infor- mation systems: new instruments for ecological research, nature conservation, and policy making. - Plant Biosystems 145(Supplement): 85-90.

Seo, C., Thorne, J.H., Hannah, L., Thuiller, W. (2009): Scale effects in species distribution models: implications for conservation planning under climate change. Biology Letters 5: 39-43. CrossRef

Stanisci, A., Acosta, A.T.R., Ercole, S., Blasi, C. (2004): Plant communities on coastal dunes in Lazio (Italy). - Annali di Botanica nuova serie vol. 4: 115-128.

van der Maarel, E. (1975): The BraunBlanquet approach in perspective. Vegetatio 30: 213-219.

Venanzoni, R., Landucci, F., Panfili, E., Gigante, D. (2012): Toward an Italian national vegetation database: Vegltaly. - In: Dengler, J., Oldeland, J., Jansen, F., Chytrý, M., Ewald, J., Finckh, M., Glöckler, F., Lopez-Gonzalez, G., Peet, R.K., Schaminée, J.H.J. (2012) [Eds.]:
Vegetation databases for the 21st century. - Biodiversity \& Ecology 4: 185190. Hamburg: Biocentre Klein Flottbek and Botanical Garden. CrossRef

Westhoff, V., van der Maarel, E. (1973): The Braun-Blanquet approach. - In: Whittaker, R.H. [Ed.]: Classification of plant communities: 289-399. The Hague, NL: Junk.

Irene Prisco* (iprisco@uniroma3.it),

Marta Carboni (mcarboni@uniroma3.it)

\& Alicia Teresa Rosario Acosta

(acosta@uniroma3.it)

Dipartimento di Biologia Ambientale,

Università degli Studi "Roma Tre"

Viale G. Marconi 446,

00146 Roma, ITALY

*Corresponding author 